\title{
Pelatihan Dan Penerapan Sistem Akuntansi Pada BUMDes Di Kabupaten Bengkayang
}

\author{
Dokman Maulitua Situmorang \\ Sekolah Tinggi Ilmu Manajemen Shanti Bhuana \\ Email : dokman@shantibhuana.ac.id
}

\begin{abstract}
There are 122 villages in Bengkayang Regency, this number is very potential to be developed into a place of employment for the local community. But the problems that arise in the field, from a total of 122 villages, not all villages have formed BUMDes even those that have been formed and are active in business activities in the last 3 years have only been around 5 Bumdes, then this has become a major problem and a difficult task for the Government Office Bengkayang Regency Village in spurring villages to have BUMDes. The aim of community service is to help the village government office and Bumdes that have been formed in Bengkayang district in carrying out good financial management and in accordance with generally accepted accounting using a simple accounting application. There is also the target is BUMDes management understands and understands about a good financial management system. This activity will greatly assist the BUMDes management to run the program and its financial system. Funds for activities that will be carried out are socialization and training. The results of this activity make a Ms. Exel files to assist Bumdes in carrying out accounting books.
\end{abstract}

Keywords: BUMDes; Accounting; Socialization; Training.

\begin{abstract}
Abstrak
Ada 122 Desa yang ada di Kabupaten Bengkayang, jumlah ini sangatlah potensial untuk di kembangkan menjadi tempat lapangan kerja bagi masyarakat setempat. Namum permasalahan yang timbul di lapangan, dari total 122 Desa, tidak semua desa sudah membentuk BUMDes bahkan yang sudah terbentuk dan aktif dalam kegiatan bisnis dalam 3 tahun terakhir baru ada sekitar 5 Bumdes, maka hal ini menjadi masalah yang besar dan tugas berat bagi Dinas Pemerintah Desa Kabupaten Bengkayang dalam memacu desa agar memeiliki BUMDes. Tujuan pengabdian kepada masyarakat ini adalah untuk membantu pihak Dinas pemerintah desa dan pihak Bumdes yang sudah terbentuk di kabupaten Bengkayang dalam melakukan tata kelola keuangan yang baik dan sesuai degan akuntansi yang berlaku umum dengan memakai aplikasi akuntansi yang sederhana. Ada pun targetnya adalah pengelolah BUMDes mengerti dan paham tentang sistem pengeloaan keuangan yang baik. Kegiatan ini akan sangat membantu pihak pengelolah BUMDes untuk menjalankan program dan sistem keuangannya. Dana kegiatan yang akan di lakukan adalah sosialisasi dan pelatihan. Hasil dari kegiatan ini menghasilkan suatu produk Ms. Exel untuk membantu Bumdes dalam melakukan pembukuan akuntansi.
\end{abstract}

Kata Kunci: BUMDes; Akuntansi; Sosialisasi; Pelatihan. 


\section{Pendahuluan}

Badan Usaha Milik Desa (BUMDes) merupakan lembaga usaha desa yang dikelola oleh masyarakat dan pemerintahan desa dalam upaya memperkuat perekonomian desa dan dibentuk berdasarkan kebutuhan dan potensi desa. BUMDes merupakan pilar kegiatan ekonomi di desa yang berfungsi sebagai lembaga sosial (social institution) dan komersial (comercial institution). Pendirian BUMDes dilandasi oleh UU No. 32 tahun 2004 jo. UU No. 23 tahun 2014 tentang Pemerintahan Daerah, UUNo. 6 tahun 2014 tentang Desa serta PP No. 72 tahun 2005 tentang Desa. Dalam UU No. 32 tahun 2004 juncto UU No. 23 tahun 2014 tentang Pemerintahan Daerah. Potensi yang dimiliki BUMDes sebagai lembaga usaha mandiri masyarakat desa dalam memberikan kesejahteraan masyarakat desa sendiri.

Sehingga keberadaan desa baik sebagai lembaga pemerintahan maupun sebagai entitas kesatuan masyarakat hukum adat menjadi sangat penting dan strategis. Sebagai lembaga pemerintahan, desa merupakan ujung tombak pemberian layanan kepada masyarakat. Sedangkan sebagai entitas kesatuan masyarakat hukum, desa merupakan basis sistem kemasyarakatan bangsa Indonesia yang sangat kokoh sehingga dapat menjadi landasan yang kuat bagi pengembangan sistem politik, ekonomi, social budaya, dan hankam yang stabil dan dinamis. Sehingga desa merupakan miniature dan sample yang sangat baik untuk mengamati secara seksama interaksi antara pemerintah dengan masyarakatnya. Dan melalui desa inilah badan usaha milik desa dapat diselenggarakan dengan mengacu pada peraturan desa yang didasarkan pada peraturan daerah (Ramadana \& Ribawanto, 2010).

Melalui alokasi dana desa, desa ataupun kelurahan berpeluang untuk mengelola pembangunan, pemerintahan dan sosial kemasyarakatan desa secara otonom. Alokasi dana desa adalah dana yang diberikan kepada desa yang berasal dari dana perimbangan keuangan pemerintah pusat dan daerah yang diterima oleh Kabupaten/Kota. Pemberian Alokasi Dana Desa merupakan wujud dari pemenuhan hak desa untuk menyelenggarakan otonominya agar tumbuh dan berkembang mengikuti pertumbuhan dari desa itu sendiri berdasarkan keanekaragaman, partisipasi, otonomi asli, demokratisasi, pemberdayaan masyarakat dan meningkatkan peran Pemerintah Desa dalam memberikan pelayanan dan meningkatkan kesejahteraan masyarakat serta memacu percepatan pembangunan dan pertumbuhan wilayahwilayah strategis.

Alokasi dana desa sangat penting guna pembiayaan pengembangan wilayah tertinggal dalam suatu sistem wilayah pengembangan. Pelaksanaan alokasi dana desa ini ditujukan untuk program-program fisik dan non fisik yang berhubungan dengan indikator perkembangan desa, meliputi tingkat pendidikan, tingkat pendapatan masyarakat, dan tingkat kesehatan.

Untuk mencapai tujuan pembangunan nasional, desa merupakan agen pemerintah terdepan yang dapat menjangkau kelompok sasaran riil yang hendak disejahterakan, yaitu dengan membentuk suatu badan usaha yaitu Badan Usaha Milik Desa yang sesuai dengan permendagri nomor 39 tahun 2010 tentang badan usaha milik desa, yang menyebutkan bahwa "untuk meningkatkan kemampuan keuangan pemerintah desa dalam penyelenggaraan pemerintahan dan meningkatkan pendapatan masyarakat melalui berbagai kegiatan usaha ekonomi masyarakat pedesaan, didirikan badan usaha milik desa sesuai dengan kebutuhan dan potensi desa".

BUMDes ini diharapkan juga mampu menstimulasi dan menggerakkan roda perekonomian di pedesaan. Aset ekonomi yang ada di desa harus dikelola sepenuhnya oleh masyarakat desa. Substansi dan filosofi BUMDes harus dijiwai dengan semangat kebersamaan dan self help sebagai upaya memperkuat aspek ekonomi kelembagaannya. Pada tahap ini, 
BUMDes akan bergerak seirama dengan upaya meningkatkan sumber-sumber pendapatan asli desa, menggerakkan kegiatan ekonomi masyarakat di mana peran BUMDes sebagai institusi payung dalam menaungi. Upaya ini juga penting dalam kerangka mengurangi peran freerider yang seringkali meningkatkan biaya transaksi dalam kegiatan ekonomi masyarakat melalui praktek rente (Nucholis, 2011).

Ada 122 Desa yang ada di Kabupaten Bengkayang, jumlah ini sangatlah potensial untuk dikembangkan menjadi tempat lapangan kerja bagi masyarakat setempat. Namun permasalahan yang timbul di lapangan, dari total 122 Desa tidak semua desa sudah membentuk BUMDes bahkan yang sudah terbentuk dan aktif dalam kegiatan bisnis dalam 3 tahun terakhir baru ada sekitar 5 BUMDes, maka hal ini menjadi masalah yang besar dan tugas berat bagi Pemerintah Desa Kabupaten Bengkayang dalam memacu desa agar memiliki BUMDes.

Dalam pengelolaan BUMDes, sangat diperlukan sistem dan manajemen yang profesional sehingga bisa konsisten dalam keberlangsungan usaha dari BUMDes tersebut, maka permasalahan yang terjadi pada BUMDes yang ada di Kabupaten Bengkayang adalah: belum siapnya para pengelola BUMDes yang sudah terpilih dalam mengelola BUMDes baik dari sisi manajemen dan sistem keuangan. Sehingga sistem pengelolaan keungan dan manajemen belum ada untuk dapat dierapkan di BUMDes. Dari permasalahan yang dihadapi perlu dilakukan suatu tindakan baik itu berupa sosialisasi dan pelatihan kepada desa-desa yang sudah terbentuk manajemennya tetapi tidak berjalan sesuai dengan yang diharapkan.

Laporan keuangan merupakan sebuah produk yang dihasilkan oleh bidang atau disiplin ilmu akuntansi. Oleh karena itu, dibutuhkan Sumber Daya Manusia (SDM) yang kompeten untuk menghasilkan sebuah laporan keuangan yang berkualitas. Kompetensi sumber daya manusia adalah kemampuan seseorang atau individu suatu organisasi (kelembagaan) atau suatu sistem untuk melaksanakan fungsi-fungsi atau kewenangannya untuk mencapai tujuannya secara efektif dan efisien (Emilda Ihsanti, 2014).

Target yang akan dicapai dalam kegiatan pengabdian kepada masyarakat ini adalah membantu pihak pemerintah desa dan pihak BUMDes yang sudah terbentuk di kabupaten Bengkayang dalam melakukan tata kelola keuangan yang baik dan sesuai dengan akuntansi yang berlaku umum dengan memakai aplikasi akuntansi yang sederhana.

Luaran yang diharapkan dalam kegiatan pengabdian kepada masyarakat ini adalah mengatur dan menata kelembagaan adminitrasi keuangan sehingga dengan hal ini dapat membekali masyarakat yang menjadi pengurus BUMDes memahami tugas pokok dan tanggungjawabnya dalam mengelola dana BUMDes, dapat lebih bertambah bidang usaha yang di tekuni sehingga kesejahteraan masyarakatnya meningkat.

\section{Pelaksanaan Dan Metode}

Berbagai komponen kekuatan desa mendirikan Badan Usaha Milik Desa (BUMDes) sebagai payung hukum untuk mengembangkan aset yang dapat dijadikan sebagai sumber penghidupan berkelanjutan (Abdur Rozaki, 2019). Metode pelaksanaan dalam kegiatan pengabdian kepada masyarakat ini dilakukan dengan beberapa tahap, sehingga menghasilkan kegiatan yang bermanfaat dan sehingga perangkap bumdes mampu bekerja dengan baik dan maksimal. Dengan demikian tahapan atau langkah-langkah yang dilakukan dalam kegiatan ini dan solusi yang ditawarkan untuk mengatasi permasalahan yang memuat hal-hal berikut ini.

a. Memberikan seminar tentang sistem keuangan BUMDes yang terdiri dari :

1. Pengenalan Akuntansi.

2. Pengenalan Manajemen Keuangan. 
b. Memberikan pelatihan tentang akuntansi desa dan manajemen desa.

Pelatihan merupakan proses yang telah direncanakan untuk memodifikasi perilaku sikap, pengetahuan serta keahlian individu melalui pengalaman belajar yang intens demi mendapatkan kinerja yang kebih efektif dalam berbagai aktivitas atau kegiatan (Ayu \& Damayanthi, 2018).

Melalui sosialisasi sistem akuntansi BUMDes berbasis web, pelatihan akuntansi BUMDes berbasis web dalam pencatatan dan pelaporan keuangan BUMDes, penguatan tata kelola BUMDes serta monitoring dan evaluasi (Erlina. Sirojuzilam, 2020)

Adapun rodmap dari kegiatan pengabdian kepada masyarakat ini sebagaimana gambar 1 di bawah ini :

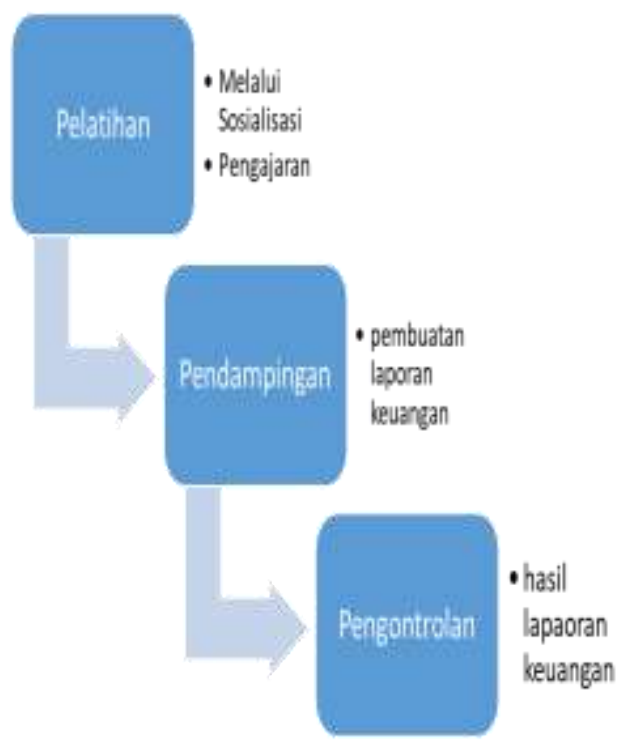

Gambar 1. Roadmap Kegiatan

\section{Hasil dan Pembahasan}

Badan usaha milik desa (atau diakronimkan menjadi BUMDes) merupakan usaha desa yang dikelola oleh pemerintah desa, dan berbadan hukum. Pemerintah desa dapat mendirikan badan usaha milik desa sesuai dengan kebutuhan dan potensi desa. Pembentukan badan usaha milik desa ditetapkan dengan peraturan desa. Kepengurusan badan usaha milik desa terdiri dari pemerintah desa dan masyarakat desa setempat (Mandiri, Ponggok, \& Priharjanto, 2019)

Laporan keuangan merupakan salah satu hal yang terpenting dalam kegiatan bisnis dan usaha, ketika laporan keuangan yang dimiliki suatu perusahaan jelas dan dapat dimengerti oleh pimpinan perusahaan dan pemilik perusahaan. maka akan ada analisis dan tindakan yang baik dan benar di dalam suatu kebijakan di perusahaan itu.

Proses penyusunan laporan keuangan BUMDes disusun dengan format laporan keuangan jasa dan hanya membuat laporan laba rugi dan laporan modal, proses pertanggungjawaban keuangan sudah dilakukan dengan baik dimana dibuktikan dengan pemahaman dari anggota BUMDes akan laporan yang dilaporkan walaupun hanya dalam bentuk laporan keuangan yang sederhana (Dwidiyantini, Luh, Erni, \& Sujana, 2017).

BUMDes juga membutuhkan laporan keuangan yang baik dan benar juga, karena BUMDes menggunakan dana pemerintah sehingga dibutuhkan ketelitian dalam menggunakan dananya agar kedepannya tidak terjadi hal-hal yang tidak diinginkan, seperti penyelewengan dana dan seterusnya.

Dalam kegiatan pengabdian kepada masyarakat ini membutuhkan 2 jenis kegiatan yang dilakukan yaitu pertama akan dilakukan kegiatan sosialisasi atau pemberian materi tentang akuntansi, dan kedua dilakukannya praktek atau langsung pelatihan kepada bagian keuangan dan perangkat BUMDes yang terpilih atau yang sudah terpilih.

\section{Sosialisasi dan Pelatihan}

Kegiatan sosialisasi ini bertujuan untuk memberikan pengetahuan kepada pengurus BUMDes tentang akuntansi dan keuangan yang baik dalam sebuah usaha atau bisnis, kegiatan sosialisasi ini di lakukan dari bulan Agustus 2019 sampai November 2019 di beberapa desa yang sudah terbentuk kepengurusan BUMDes. Kinerja BUMDes tentu sangat dipengaruhi 
oleh kinerja manajemen beserta karyawan yang ada. Dengan demikian, jika ingin meningkatkan kinerja organisasi BUMDes maka kemampuan pengurus BUMDes (manajemen dan karyawan) perlu ditingkatkan (Tyasasih \& Triska Dewi Pramitasari, 2019).

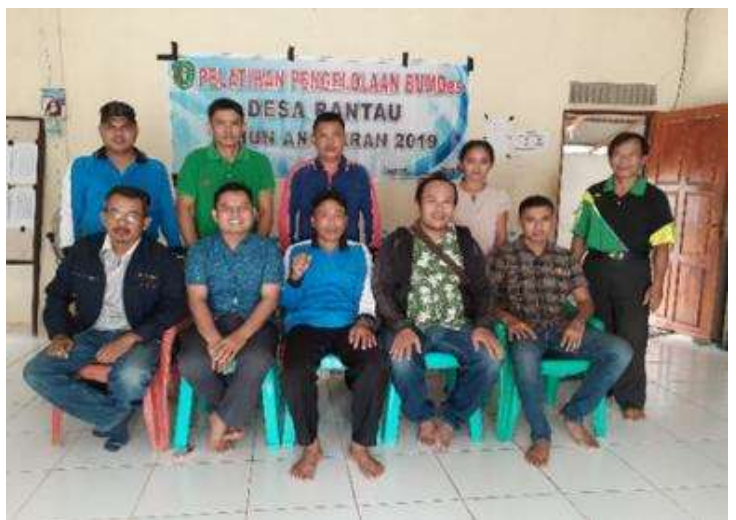

Gambar 2. Sosialisasi \& Pelatihan di desa Rantau

BUMDes di desa ini sudah terbentuk, namun belum berjalan. Adapun jenis usaha yang akan dijalankan adalah usaha isi ulang air minum. Karena di daerah ini penyediaan isi ulang air minum bersih belum ada, dan saluran air bersih juga belum ada sehingga ini merupakan peluang bagi BUMDes yang akan terbentuk dan berjalan.

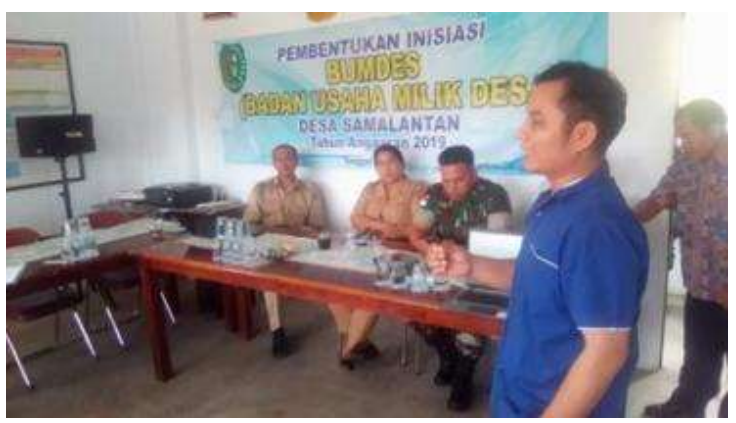

Gambar 3. Sosialisasi \& Pelatihan di desa Samalantan

Desa samalantan ini akan menjalankan bisnis usaha yang terdiri dari, bisnis usaha penjualan gas elpiji $3 \mathrm{~kg}$, serta penanaman dan penjualan jagung. Karena di desa ini masyarakatnya sangat mendukung perkembangan BUMDes maka masyarakat setempat ikut dalam pemberian lahan untuk di pakai menanam jagung.

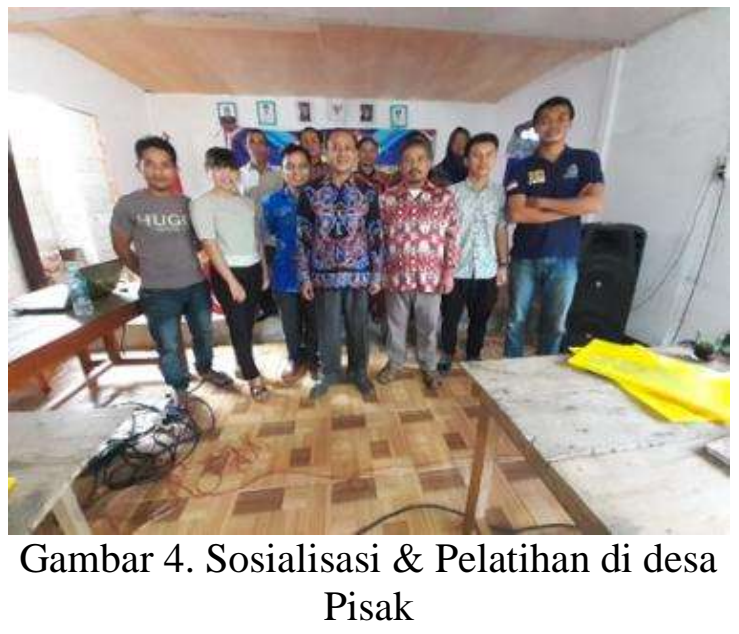

Daerah ini memiliki potensi air yang sangat besar, dimana terdapat objek wisata air terjun yang sangat indah dan menarik banyak wisatawan baik pada hari libur dan hari biasa. Maka berangkat dari potensi itu, pemerintah daerah membuka peluang untuk mendirikan BUMDes yang bergerak di bidang pariwisata dan bisnis usaha isi ulang air minum.

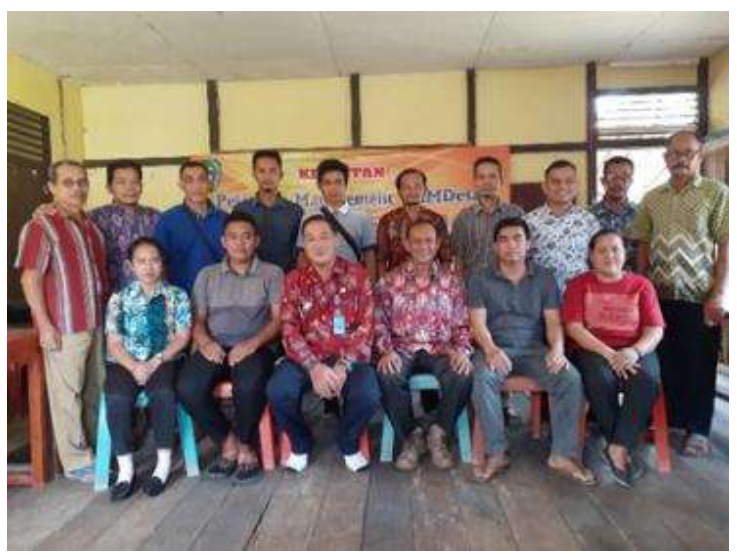

Gambar 5. Sosialisasi \& Pelatihan di desa Tempapan

Desa Tempapan merupakan salah satu desa yang terletak di lembah bawang atau gunung bawang, sehingga akses dan jalan ke desa ini masih kurang baik. Adapun usaha yang dijalankan oleh BUMDes ini adalah usaha penjualan gas elpiji $3 \mathrm{~kg}$ dan sejenisnya. 


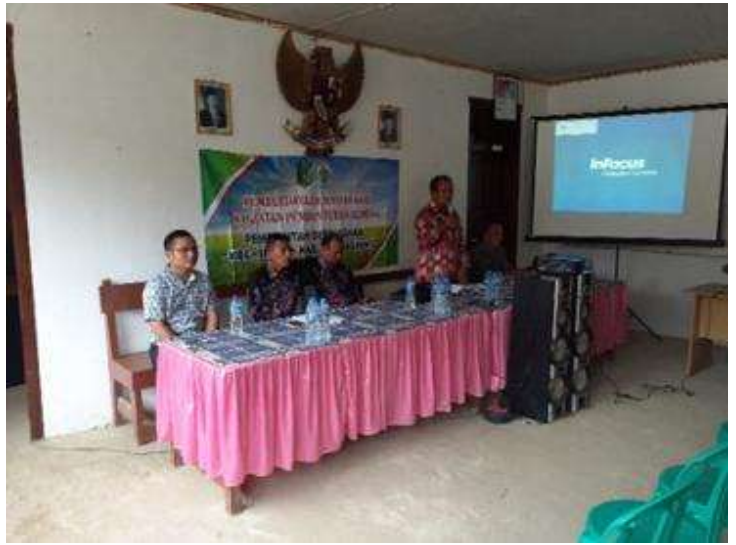

Gambar 6. Sosialisasi \& Pelatihan di desa Sahan

Desa ini sudah menerima penyertaan modal sebanyak 2 kali tahun 2018 dan tahun 2019 untuk pembentukan BUMDes, akan tetapi BUMDesnya belum berjalan dikarenakan belum diaktifkannya para pengurus BUMDes yang sudah terbentuk. Adapun usaha yang akan di jalankan adalah usaha isi ulang air minum.

\section{Hasil Produk}

Pengabdian kepada masyarakat ini bertujuan untuk meningkatkan kemampuan perangkat BUMDes khususnya bagian keuangan tentang pengetahuan akuntansi dan laporan keuangan secara umum. Sehingga perangkat BUMDes mampu menjalankan usahanya dengan baik dan benar maka perlu suatu sistem atau produk aplikasi yang harus dihasilkan sehingga perangkat BUMDes tidak bingung atau terkendala dalam menjalankan tugas dalam mengelola keuangan BUMDes.

Produk aplikasi ini ditawarkan kepada desa-desa yang ada di kabupaten Bengkayang adalah perangkat lunak laporan keuangan yang sederhana dan sistematis yang terbuat dari Ms, Exell. Perangkat lunak ini sangat membantu pihak BUMDes dalam mengelola bisnisnya karena di dalamnya sudah lengkap pencatatan jurnalnya dan menghasilkan sebuah laporan keuangan, sehingga laporan keuangan ini bisa digunakan untuk laporan kepada pihak desa dan pihak pajak. Perangkat lunak laporan keuangan ini sudah dipakai oleh beberapa BUMDes yang ada di kabupaten Bengkayang. Ada pun gambaran dari laporan keuangan itu adalah :

\section{Jurnal Umum}

Jurnal umum merupakan pencatatan awal yang di lakukan di dalam kegiatan bisnis atau usaha dalam menyimpan kegiatan transaksi yang terjadi di perusahaan. Pengertian jurnal atau catatan harian adalah formulir khusus yang dipakai untuk mencatat setiap transaksi, berdasarkan dokumen/bukti transaksi, secara kronologis sesuai akun-akun yang terpengaruh dalam jumlah tertentu dengan cara didebet atau dikredit. Maka bentuk jurnal umum yang diterapkan dalam BUMDes yang ada di Kabupaten Bengkayang adalah :

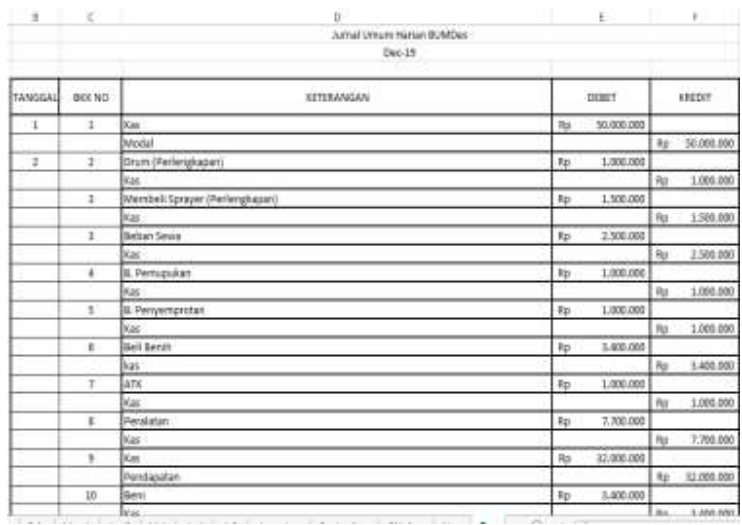

Gambar 7. Jurnal umum

\section{Buku Besar}

Buku Besar merupakan pencatatan dari semua total yang ada dalam akun bisnis akuntansi, contohnya total atau jumlah akun Kas yang sisa. Buku Besar adalah suatu catatan yang berisi kumpulan akunakun yang merupakan suatu kesatuan tersendiri dan saling berhubungan. Pencatatan transaksi dalam buku besar didasarkan pada jenis akun dan dicatat secara kronologis. Ini berlainan dengan pencatatan pada buku jurnal, dimana walaupun sudah dilakukan secara kronologis tapi akunnya masih terpisahpisah. 


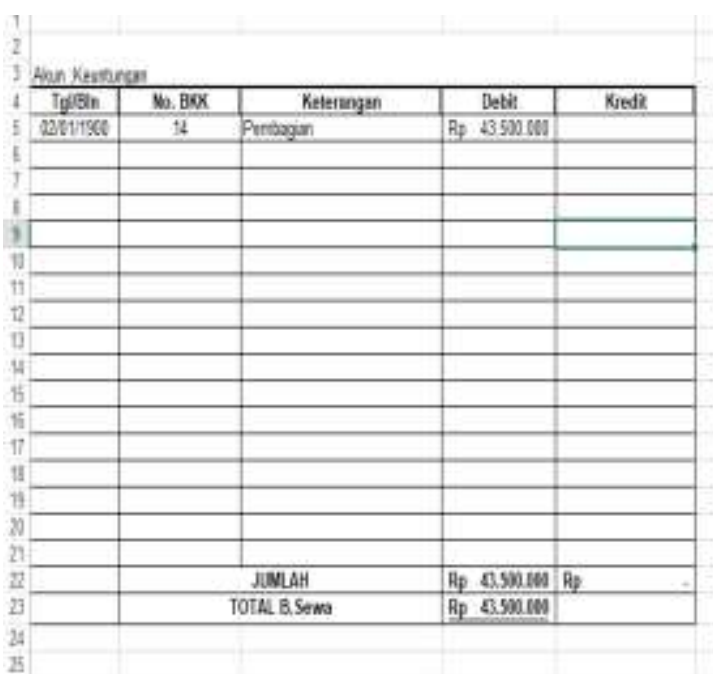

Gambar 8. Buku Besar

\section{Neraca Saldo}

Neraca Saldo merupakan penggabungan dari semua total akun-akun yang ada dalam transaksi akuntansi selama 1 periode akuntansi. Sumber pencatatan neraca saldo adalah buku besar. Jika perusahaan menggunakan akun bentuk stafel (tiga atau empat kolom), penyusunan neraca saldo tinggal mencatat saldo terakhir masing masing akun buku besar.

\begin{tabular}{|c|c|c|c|c|}
\hline \multirow{3}{*}{$\begin{array}{l}1 \\
2 \\
3\end{array}$} & \multicolumn{4}{|c|}{ LAPORAK NERACA BUMDES } \\
\hline & No. & \multirow{2}{*}{ MANA NWUN } & \multicolumn{2}{|c|}{ NERACA SALDO } \\
\hline & GKUK & & DEBAT & KFEDIT \\
\hline 4 & 7110 & Kas & 3100000 & \\
\hline 5 & 1120] & Pitang Dagang & & \\
\hline 6 & 1130 & Persedam toos paba & & \\
\hline 7 & 112) & Persedani Eararg Dajangan & 8 & \\
\hline 8 & 2210 & tanat: & & \\
\hline 9. & 1200 & Gains & & \\
\hline 10 & 1225 & Ax Peryussian Gedang & & \\
\hline 11 & 1230 & Kendaran & & \\
\hline 12 & 1235 & Perlendapan Kartor & 25600000 & \\
\hline 13 & 1220 & Peraztan tartor & 170000 & \\
\hline 14 & 128 & As Penpusitan Persiatan KTR & & \\
\hline 15 & 2110 & Hitarg Dagang. & & \\
\hline 16 & 2270 & Hatarg Bask & & \\
\hline 17 & 2220 & Hictarg jarola Parnang Lamia & & \\
\hline 18 & 3110 & Hoda & & 5470000 \\
\hline 19 & 3120 & Laba Bian Eeralat & & \\
\hline 20 & 3130 & Pug L L ba serjalan & & \\
\hline 21 & 1500 & Keimusan & 43560000 & \\
\hline 2u. & $41+0$ & Pendaparan & & 52000000 \\
\hline 23 & 5500 & Feum Pelux: & & \\
\hline 24 & 4130 & Persedass & 5400.000 & \\
\hline 25 & 4120 & Lata Penualan $A K$ Tetap & & \\
\hline
\end{tabular}

Gambar 9. Neraca Saldo

\section{Laporan Laba/Rugi}

Dalam sebuah bisnis usaha, laporan laba rugi merupakan salah satu laporan yang sangat diperhatikan atau disorot penting dalam penentuan jejak dan langkah suatu bisnis itu berjalan dengan baik atau lancar. Laporan laba rugi adalah laporan yang menunjukkan kemampuan perusahaan atau entitas bisnis dalam menghasilkan keuntungan selama suatu periode tertentu. Dalam laporan laba rugi terdapat unsur akun nominal, yakni akun pendapatan dan akun beban.

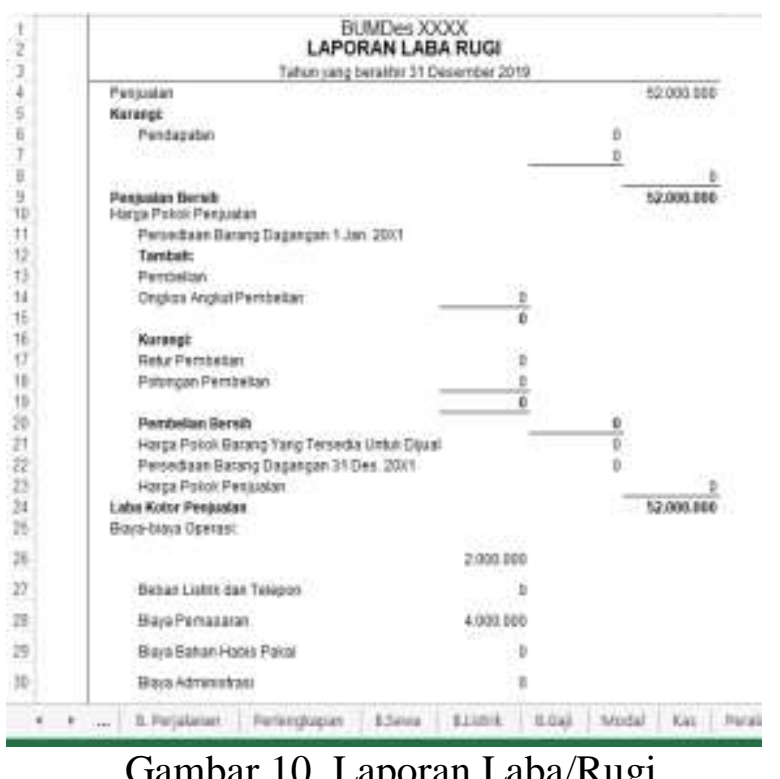

\section{Laporan Perubahan Modal}

Laporan perubahan modal merupakan laporan untuk mengetahui sisa dari jumlah modal yang sudah di tanamkan oleh pemilik modal kepada perusahaan, dalam hal ini desa yang ada di atas BUMDes tersebut. Laporan perubahan ekuitas adalah laporan yang menggambarkan perubahan ekuitas suatu perusahaan dalam suatu periode tertentu.

\section{BUMDES XXX LAPORAN PERUBAHAN MODAL Perlode 1 Januarl - 31 Desember 2001}

\begin{tabular}{|c|c|}
\hline Modal, per 1 Janusizox & 58700000 \\
\hline Laba Rug thun $20 \times 1$ & $43500000+$ \\
\hline & 102200000 \\
\hline Phive & 43.500000 \\
\hline Modal per 31 Desember 2001 & 58.7000000 \\
\hline
\end{tabular}

Gambar 11. Laporan Perubahan Modal 


\section{Laporan Neraca}

Laporan neraca merupakan laporan penentuan keuangan apakah keuangan itu seimbang dalam hal aktiva dan passiva di perusahaan, maka dari laporan neraca ini kita dapat mengetahui asset perusahaan, modal perusahaan, dan hutang perusahaan. Neraca adalah laporan keuangan yang menggambarkan kondisi keuangan suatu perusahaan pada tanggal tertentu. Neraca menyajikan akun rill yaitu asset, kewajiban, dan modal.

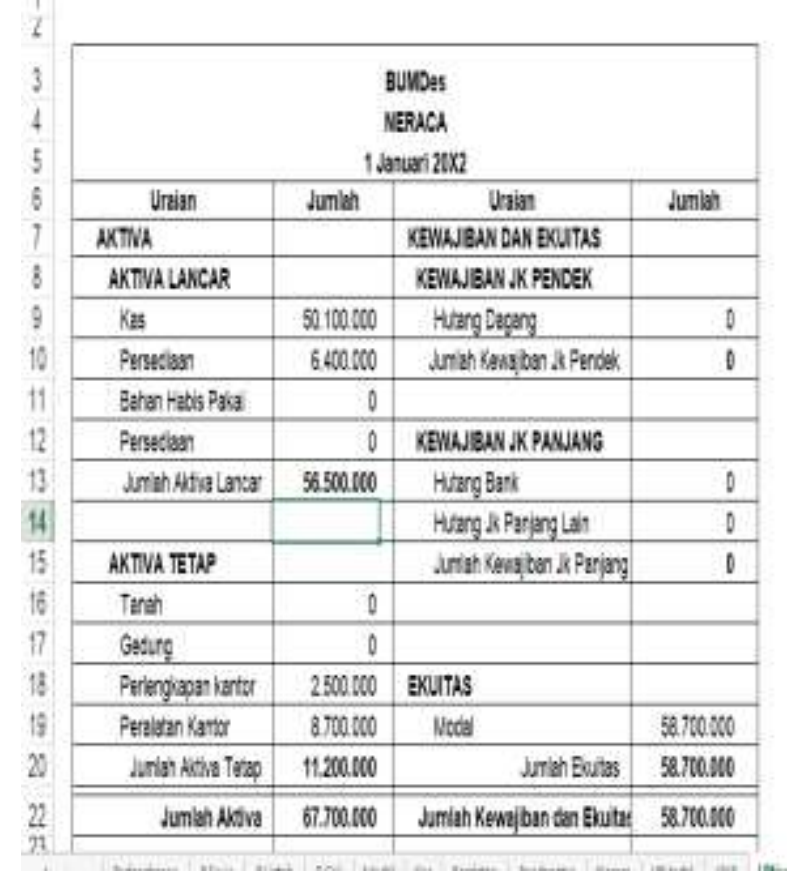

Gambar 12. Laporan Neraca

\section{Penutup}

\section{Simpulan}

Sosialisasi dan pelatihan sistem akuntansi di kabupaten Bengkayang dalam hal ini untuk perangkat BUMDes sangat penting, hal itu dapat di temukan oleh peneliti bahwa hampir semua perangkat desa tidak mengerti sistem keuangan akuntansi yang baik dan berstandar umum, maka dengan software Ms. Exell ini perangkat BUMDes yang ada di kabupaten Bengkayang dapat menjalankan bisnis usaha dengan baik dan benar tampa harus kesulitan lagi dalam pencatatan keuangan serta pelaporan keuangan kepada pihak yang berwajib menerima laporan dan kepada kantor pajak. Penelitian ini di dukung oleh (Perdanawati1, Rasmini2, \& Dewa Gede Wirama3, 2014)(Perdanawati1 et al., 2014) bahwa aplikasi sistem akuntansi sangat membantu pihak di dinas pendidikan tinggi Bali.

Pelaksanaan sosialisasi dan pelatihan keterampilan manajemen dan akuntansi bagi pengurus BUMDes mendapat respon yang positif dari peserta pelatihan yang merupakan pengurus BUMDes dan perangkat desa. Semua peserta memberikan feed back bahwa sosialisasi dan pelatihan ini sangat memberikan manfaat bagi peningkatan keterampilan manajemen dan akuntansi BUMDes.

\section{Saran}

Saran bagi pihak pemerintah Kabupaten Bengkayang khususnya Pemerintah Desa, agar lebih gencar dalam melakukan sosialisasi dan pelatihan akuntansi Bumdes.

\section{Ucapan Terima Kasih}

Penulis sampaikan terima kasih kepada pihak yang mensponsori kegiatan pengabdian kepada masyarakat ini yaitu Sekolah Tinggi Ilmu Manajemen Shanti Bhuana dan pihak Pemerintah Kabupaten Bengkayang khususnya Plt. Kepala Desa (Bpk. Dodorikus. AP).

\section{Daftar Pustaka}

Abdur Rozaki, S. R. (2019). Memberdayakan Desa Melalui Pariwisata Berbasis Bumdes : Studi Interkoneksi Bumdes Melalui Integrated Information. Engagement Jurnal Pengabdian Kepada Masyarakat, 3(3), 237-241.

Ayu, I. G., \& Damayanthi, E. (2018). Pengaruh Pelatihan, Dukungan Manajemen Puncak , Kejelasan Tujuan, Kemampuan Teknik Personal Pada Penggunaan Sistem Informasi Akuntansi, 22, 138-157.

Dwidiyantini, K. A., Luh, N., Erni, G., \& Sujana, E. (2017). Badan Usaha Milik Desa ( Bumdes ) Tugu Sari Pajahan. EJurnal Akuntansi Universitas Udayana, $7(1)$. 
Emilda Ihsanti. (2014). Pengaruh Kompetensi Sumber Daya Manusia Dan Penerapan Sistem Akuntansi Keuangan Daerah Terhadap Kualitas Laporan Keuangan Daerah (Studi Empiris Pada Skpd Kab. Lima Puluh Kota). E-Journal S1 Ak Universitas Pendidikan Ganesha, 7(1).

Erlina. Sirojuzilam. (2020). Sosialiasi Penerapan Sistem Pencatatan Dan Pelaporan Keuangan Bumdes Berbasis Web. Riset \& Jurnal Akuntansi, 4(1), 282-287.

Mandiri, B. T., Ponggok, D., \& Priharjanto, A. (2019). Pendampingan Perancangan Kebijakan Akuntansi Berdasarkan Sak Etap Dalam Pelaporan Keuangan Pada Bumdes Tirta Mandiri, Desa Ponggok, Klaten. Jurnal Keuagan Umum Dan Akuntansi Terapan, 1(3), 1-10.

Nucholis. (2011). Pertumbuhan Dan Penyelenggaraan Pemerintah Desa. Jakarta: Erlangga.

Perdanawati1, L. P. V. I., Rasmini2, N. K., \& Dewa Gede Wirama3. (2014). Pengaruh Unsur-Unsur Kepuasan Pengguna Pada Efisiensi Dan Efektivitas Kerja Pengguna Aplikasi Sistem Akuntansi Instansi Di Satuan Kerja Pendidikan Tinggi Di Provinsi Bali. E-Jurnal Ekonomi Dan Bisnis Universitas Udayana 3.8, 03(08).

Ramadana, C. B., \& Ribawanto, H. (2010). Keberadaan Badan Usaha Milik Desa (Bumdes) Sebagai Penguatan Ekonomi Desa (Studi di Desa Landungsari, Kecamatan Dau, Kabupaten Malang). Jurnal Administrasi Publik (JAP, 1(6), 1068-1076.

Tyasasih, R., \& Triska Dewi Pramitasari. (2019). Pelatihan Akuntansi dan Manajemen Dalam Rangka Pengelolaan Bumdes Di Desa Tanjung Glugur, Kabupaten Situbondo. Comvice, 3(2), 1118.

Peraturan Menteri Dalam Negeri Nomor 39 Tahun 2010 tentang Badan Usaha Milik Desa (c.2). Jakarta, Menteri Dalam Negeri. 